\title{
PERANAN GURU DALAM MENINGKATKAN MOTIVASI BELAJAR SISWA
}

\author{
Arianti \\ arianti01@gmail.com \\ SMA Negeri 14 Bone, Sulawesi Selatan
}

\begin{abstract}
The role of teachers in improving student learning motivation is one of the integral activities that must be in learning activities. In addition to providing and transferring teacher knowledge is also tasked to improve children's motivation in learning. It cannot be denied that student learning with others is very different, that's why it is important for teachers to always motivate students so that students always have the spirit of learning and being able become students who excel and can develop themselves optimally. The learning process will succeed if students have motivation in learning. Therefore, teachers need to foster optimal student motivation. Teachers are demanded to be creative to arouse student learning motivation. Learning motivation is meaningfulness, value, and the benefits of learning learning activities are quite interesting for students to do learning activities.
\end{abstract}

Keywords: Teachers' role, students' motivation, learning motivation

\section{PENDAHULUAN}

Pendidikan adalah usaha sadar untuk menumbuh kembangkan potensi sumber daya manusia melalui kegiatan pengajaran. Salah satu faktor dari dalam diri yang menentukan berhasil tidaknya dalam proses belajar mengajar adalah motivasi belajar. Dalam kegiatan belajar, motivasi merupakan keseluruhan daya penggerak di dalam diri yang menimbulkan kegiatan belajar,yang menjamin kelangsungan dari kegiatan belajar. Motivasi belajar adalah merupakan faktor psikis yang bersifat non intelektual. Seseorang yang mempunyai intelegensi yang cukup tinggi, bisa gagal karena kurang adanya motivasi dalam belajarnya.

Motivasi mempunyai peranan penting dalam proses belajar mengajar baik bagi guru maupun siswa. Bagi guru mengetahui motivasi belajar dari siswa sangat diperlukan guna 
memelihara dan meningkatkan semangat belajar siswa. Bagi siswa motivasi belajar dapat menumbuhkan semangat belajar sehingga siswa terdorong untuk melakukan perbuatan belajar. Siswa melakukan aktivitas belajar dengan senang karena didorong motivasi.

Saat ini, banyak siwa yang kurang termotivasi untuk belajar. Hal tersebut dapat di lihat dari sikap siswa yang acuh terhadap proses pembelajaran, tidak memperhatikan guru ketika menjelaskan materi serta tidak mengerjakan tugas yang diberikan oleh guru.

Penguatan dan penanaman motivasi belajar berada di tangan para guru. Karena selain siswa, unsur terpenting yang ada dalam kegiatan pembelajaran adalah guru. Guru adalah pendidik yang berperan dalam rekayasa pedagogik. Ia menyusun desain pembelajaran dan dilaksanakan dalam proses belajar mengajar. Guru juga berperan sebagai pendidik yang mengajarkan nilai-nilai, akhlak, moral maupun sosial dan untuk menjalankan peran tersebut seorang guru dituntut untuk memiliki pengetahuan dan wawasan yang luas yang nantinya akan diajarkan kepada siswa.

\section{A. Peran dan Fungsi Guru dalam Proses Pembelajaran}

Guru menurut UU no. 14 tahun 2005 "adalah pendidik profesional dengan tugas utama mendidik, mengajar, membimbing, mengarahkan, melatih, menilai, dan mengevaluasi peserta didik pada pendidikan anak usia dini jalur pendidikan formal, pendidikan dasar, dan pendidikan menengah."

Dalam dunia pendidikan, istilah guru bukanlah hal yang asing. Menurut pandangan lama, guru adalah sosok manusia yang patut digugu dan ditiru. Digugu dalam arti segala ucapannya dapat dipercaya. Ditiru berarti segala tingkah lakunya harus dapat menjadi contoh atau teladan bagi masyarakat.

Perkembangan baru terhadap pandangan belajar mengajar membawa konsekuensi kepada guru untuk meningkatkan peranan dan kompetensinya karena proses belajar mengajar dan hasil belajar siswa sebagian besar ditentukan oleh peranan dan kompetensi guru. Guru yang kompeten akan lebih mampu mengelola kelasnya sehingga hasil belajar siswa berada pada tingat optimal.

Peran seorang guru sangatlah signifikan dalam proses belajar mengajar. Peran guru dalam proses belajar mengajar meliputi banyak hal seperti sebagai pengajar, manajer kelas, supervisor, motivator, konsuler, eksplorator, dsb. Yang akan dikemukakan disini adalah peran yang dianggap paling dominan dan klasifikasi guru menurut Uzer Usman (2007:9) adalah sebagai: 


\section{Guru sebagai Demonstrator}

Melalui peranannya sebagai demonstrator, lecturer, atau pengajar, guru hendaknya senantiasa menguasai bahan atau materi pelajaran yang akan diajarkannya serta senantiasa mengembangkannya dalam arti meningkatkan kemampuannya dalam hal ilmu yang dimilikinya karena hal ini akan sangat menetukan hasil belajar yang dicapai oleh siswa. Salah satu hal yang harus diperhatikan oleh guru ialah bahwa ia sendiri adalah pelajar. Ini berarti bahwa guru harus belajar terus-menerus. Dengan cara demikian ia akan memperkaya dirinya dengan berbagai ilmu pengetahuan sebagai bekal dalam melaksanakan tugasnya sebagai demonstrator sehingga mampu memperagakan apa yang diajarkannya secara didaktis. Maksudnya ialah agar apa yang disampaikannya itu betul-betul dimiliki oleh anak didik.

\section{Guru Sebagai Pengelola Kelas}

Mengajar dengan sukses berarti harus ada keterlibatan siswa secara aktif untuk belajar.Keduanya berjalan seiring, tidak ada yang mendahului antara mengajar dan belajar karena masing-masing memiliki peran yang memberikan pengaruh satu dengan yang lainnya. Keberhasilan/kesuksesan guru mengajar ditentukan oleh aktivitas siswa dalam belajar, demikian juga keberhasilan siswa dalam belajar ditentukan pula oleh peran guru dalam mengajar. Mengajar berarti menyampaikan atau menularkan pengetahuan dan pandangan (Ad.Rooijakkers, 1990:1). William Burton mengemukakan bahwa mengajar diartikan upaya memberikan stimulus, bimbingan, pengarahan, dan dorongan kepada siswa agar terjadi proses belajar. Dalam hal ini peranan guru sangat penting dalam mengelola kelas agar terjadi PBM dapat berjalan dengan baik.

\section{Guru sebagai Mediator}

Sebagai mediator guru hendaknya memiliki pengetahuan dan pemahaman yang cukup tentang media pendidikan karena media pendidikan merupakan alat komunikasi guna lebih mengefektifkan proses belajar-mengajar. Dengan demikian jelaslah bahwa media pendidikan merupakan dasar yang sangat diperlukan yang bersifat melengkapi dan merupakan bagian integral demi berhasilnya proses pendidikan.

\section{Guru sebagai Fasilitator}

Sebagai fasilitator guru hendaknya mampu mengusahakan sumber belajar yang kiranya berguna serta dapat menunjang pencapaian tujuan dan proses belajar-mengajar, baik yang berupa narasumber, buku teks, majalah ataupun surat kabar. 


\section{Guru sebagai Evaluator}

Dalam dunia pendidikan, setiap jenis pendidikan atau bentuk pendidikan pada waktuwaktu tertentu selama satu periode pendidikan akan diadakan evaluasi, artinya pada waktuwaktu tertentu selama satu periode pendidikan tadi orang selalu mengadakan penilaian terhadap hasil yang telah dicapai, baik oleh pihak terdidik maupun oleh pendidik. Penilaian perlu dilakukan, karena dengan penilaian guru dapat mengetahui keberhasilan pencapaian tujuan, penguasaan siswa terhadap pelajaran, serta ketepatan atau keefektifan metode mengajar.

\section{Guru sebagai Motivator}

Sejalan dengan pergeseran makna pembelajaran dari pembelajaran yang berorientasi kepada guru (teacher oriented) ke pembelajaran yang berorientasi kepada siswa (student oriented), maka peran guru dalam proses pembelajaran pun mengalami pergeseran, salah satunya adalah penguatan peran guru sebagai motivator.

Proses pembelajaran akan berhasil manakala siswa mempunyai motivasi dalam belajar. Oleh sebab itu, guru perlu menumbuhkan motivasi belajar siswa.Untuk memperoleh hasil belajar yang optimal, guru dituntut kreatif membangkitkan motivasi belajar siswa, sehingga terbentuk perilaku belajar siswa yang efektif.

Dalam perspektif manajemen maupun psikologi, kita dapat menjumpai beberapa teori tentang motivasi (motivation) dan pemotivasian (motivating) yang diharapkan dapat membantu para manajer (baca: guru) untuk mengembangkan keterampilannya dalam memotivasi para siswanya agar menunjukkan prestasi belajar atau kinerjanya secara unggul. Kendati demikian, dalam praktiknya memang harus diakui bahwa upaya untuk menerapkan teori-teori tersebut atau dengan kata lain untuk dapat menjadi seorang motivator yang hebat bukanlah hal yang sederhana, mengingat begitu kompleksnya masalah-masalah yang berkaitan dengan perilaku individu (siswa), baik yang terkait dengan faktor-faktor internal dari individu itu sendiri maupun keadaan eksternal yang mempengaruhinya (Usman, 2009:9).

Setiap guru memiliki tugas masing-masing. Adapun yang dimaksud adalah:

Guru memiliki banyak tugas, baik yang terikat oleh dinas maupu yang di luar dinas, dalam bentuk pengabdian. Apabila kita kelompokkan terdapat tiga jenis tugas guru, yakni tugas dalam bidang profesi,tugas kemanusiaan, dan tugas dalam bidang kemasyarakatan.

Guru merupakan profesi/jabatan atau pekerjaan yang memerlukan keahlian khusus sebagai guru. Jenis pekerjaan ini tidak dapat dilakukan oleh sembarang orang di luar bidang 
kependidikan walaupun kenyataannya masih dilakukan orang di luar kependidikan.Itulah sebabnya jenis profesi ini paling mudah terkena pencemaran (Usman, 2009:6).

Tugas guru sebagai profesi meliputi mendidik, mengajar, dan melatih. Mendidik berarti meneruskan dan mengembangkan nilai-nilai hidup. Mengajak berarti meneruskan dan mengembangkan ilmu pengetahuan dan teknologi. Sedangkan melatih berarti mengembangkan keterampilan-keterampilan pada siswa.

Tugas guru dalam bidang kemanusiaan di sekolah harus dapat menjadikan dirinya sebagai orang tua kedua.Ia harus mampu menarik simpati sehingga ia menjadi idola para siswanya. Pelajaran apapun yang diberikan, hendaknya dapat menjadi motivasi bagi siswanya dalam belajar. Bila seorang guru dalam penampilannya sudah tidak menarik, maka kegagalan pertama adalah ia tidak akan dapat menanamkan benih pengakjarannya itu kepada para siswa. Para siswa akan enggan menghadapi guru yang tidak menarik. Pelajaran tidak dapat diserap sehingga setiap lapisan masyarakat (homo indens, homo puber, dan homo sapiens) dapat mengerti bila menghadapi guru.

Masyarakat menempatkan guru pada tempat yang lebih terhormat di lingkungannya karena dari seorang guru diharapkan masyarakat dapat memeperoleh ilmu pengetahuan.Ini berarti bahwa guru berkewajiban mencerdaskan bangsa menuju pembentukan manusia Indonesia seutuhnya yang berdasarkan pancasila (Mamo, 2010:18).

Adapun fungsi guru adalah sebagai berikut:

\section{Guru Sebagai Pendidik}

Salah satu fungsi guru yang umum adalah sebagai pendidik.Dalam melaksanakan fungus ini, guru dituntut menjadi inspirator dan menjaga disiplin kelas.Sebagai inspirator, guru memberikan semangat kepada para siswa tanpa memandang tingkat kemampuan intelektual atau tingkat motivasi belajarnya.Buatlah setiap siswa senang bergaul dengan guru, baik di dalam maupun di luar kelas.Hal ini tentu saja menuntut fleksibilitas yang tinggi.Perhatian dan tindakan guru harus disesuaikan dengan kebutuhan masing-masing siswa.

\section{Guru sebagai Didaktikus}

Menurut Benyamin Bloom sebagai mana dikutip W.S. Winkel (1991 : 115), kualitas pengajaran sangat bergantung pada cara menyajikan ateri yang harus dipelajari. Selain itu, bagaimana cara guru menggunakan peneguhan, bagaimana cara guru mengaktifkan siswa supaya berartisipasi dan merasa terlibat dalam proses belajar, dan bagaiman cara guru 
memberikan informasi kepada siswa tentang keberhasilan mereka, merupakan cara-cara yan biasa disampaikan. Semua hal tersebut menuntut keterampilan didaktik guru

Tugas dan fungsi guru tentu saja berkaitan dengan belajar karena belajar tidak lepas dari siswa itu sendiri. Jadi Belajar adalah modifikasi atau memperteguh kelakuan melalui pengalaman.(learning is defined as the modification or streng thening of behavior through experiencing.

Menurut pengertian di atas, belajar adalah merupakan suatu proses, suatu kegiatan dan bukan suatu hasil atau tujuan. Belajar bukan hanya mengingat, akan tetapi lebih luas dari pada itu, yakni mengalami. Hasil belajar bukan suatu penguasaan hasil latihan, melainkan perubahan kelakuan.

Pengertian ini sangat berbeda dengan pengertian lain tentang belajar, yang menyatakan bahwa belajar adalah memperoleh pengetahuan ; belajar adalah latihan-latihan pembentukan kebiasaan secara otomatis, dan seterusnya.

Dibandingkan dengan pengertian pertama, maka jelas, tujuan belajar itu prinsipnya sama,yakni perubahan tingkah laku,hanya berbeda cara atau usaha pencapainnya. Pengertian ini menitik beratkan pada interaksi antara individu dengan lingkungan.Didalam interaksi inilah terjadi serangkaian pengalaman belajar.

Bukti bahwa seseorang telah melakukan kegiatan belajar ialah adanya perubahan tingkah laku pada orang tersebut, yang sebelumnya tidak ada atau tingkah lakunya tersebut masih lemah atau kurang.Tingkah laku memiliki unsure objektif dan unsure subjektif. Unsure objektif adalah un sur motorik atau unsur jasmaniah sedangkan unsure subjektif adalah unsur rohaniah (Hamalik, 2011: 26).

\section{B. Faktor-Faktor yang Mempengaruhi Belajar}

Secara global, faktor-faktor yang mempengaruhi belajar siswa dapat kita bedakan menjadi 3 macam, yakni: faktor Internal, faktor eksternal, faktor pendekatan belajar.

Faktor-faktor diatas dalam banyak hal sering saling berkaitan dan mempengaruhi satu sama lain. Seorang siswa yang bersikaf conserving terhadap ilmu pengetahuan atau bermotif ekstrinsik (faktor eksternal) umpamanya, biasanya cenderung mengabil pendekatan belajar yang sederhana dan tidak mendalam. Sebaliknya, seorang siswa berintelijensi tinggi (faktor internal) dan mendapat dorongan positif dari orang tuanya (faktor eksternal), mungkin akan memilih pendekatan belajar yang lebih mementingkan kualitas hasil pembelajaran. 


\section{Faktor Internal Siswa}

Faktor yang berasal dari dalam diri siswa sendiri meliputi 2 aspek, yakni: aspek fisiologis (jasmani), psikologis (rohaniah).

a. Aspek Fisiologis

Kondisi umum jasmani dan tonus (tegangan otot) yang menandai tingkat kebugaran organ-organ tubuh dan sendi-sendinya, dapat mempengaruhi semangat dan intensitas siswa dalam mengikuti pelajaran.Kondisi organ tubuh yang lemah, apalagi jika disertai pusing kepala berat misalnya, dapat menurunkan kualitas ranah cipta (kognitif) sehinga materi yan di pelajarinya pun kurang atau tidak berberbekas.

b. Aspek Psikologis

Banyak faktor yang termasuk aspek psikologis yag dapat mepengaruhi kuantitas dan kualitas perolehan pembelajaran siswa. Namun, diantara faktor-faktor rohaniah siswa yan pada umumnya dipandang lebih esensial, yaitu: tingkat kecerdasan/inteligensi siswa, sikap siswa, bakat siswa, minat siswa, motivasi siswa.

\section{Faktor Eksternal Siswa}

Seperti faktor internal siswa, faktor eksternal siswa juga terdiri atas dua macam, yakni :faktor lingkungan sosial dan faktor lingkungan nonsosial.

a. Lingkungan Sosial

Lingkungan sosial sekolah seperti para guru, para staf administrasi, dan teman-teman sekelas dapat mempengaruhi semangat belajar seorang siswa. Para guru yang selalu menunjukkan sikaf dan perilaku yang simpatik dan meperlihatkan suri tauladan yang baik dan rajin khususnya dalam hal belajar, misalnya rajin membaca dan berdiskusi, dapat menjadi daya dorong yang positif bagi kegiatan belajar siswa. Selanjutnya, yang termasuk lingkungan social siswa adalah masyarakat an tetangga juga temanteman sepermainan disekitar perkampungan siswa tersebut.

b. Lingkungan Non-sosial

Faktor-faktor yang termasuk lingkungan nonsosial adalah gedung sekolah dan letaknya, rumah tempat tinggal keluarga siswa dan letaknya, alat-alat belajar, keadaan cuaca, dan waktu belajar yang digunakan siswa.Faktor-faktor ini dipandang turut menentukan tingkat keberhasilan belajar siswa. 


\section{Faktor Pendekatan Belajar}

Pendekatan belajar, seperti yang telah diuraikan secara panjang lebar pada subbab sebelumnya, dapat dipahami sebagai segala cara atau strategi yang digunakan siswa dalam menunjang keefektifan dan efisiensi proses pebelajaran materi tertentu. Strategi dalam hal ini berarti seperangkat langkah operasional yang direkayasa sedemikian rupa untuk meecahkan masalah atau mencapai tujuan belajar tertentu (Lawson, 1991).

Di samping faktor-faktor internal dan eksternal siswa sebagai mana yang telah di paparkan dimuka, faktor pendekatan belajar juga berpengaruh terhadap tarap keberhasilan proses pembelajaran siswa tersebut (Syah, 2004:114).

\section{Motivasi Belajar}

\section{Pengertian Motivasi}

Motivasi berasal dari bahasa Latin, Movere yang berarti dorongan atau daya penggerak. Banyak ahli yang sudah mengemukakan pengertian motivasi dengan berbagai sudut pandang mereka masing-masing, namun intinya sama, sebagai suatu pendorong yang mengubah energi dalam diri seseorang kedalam bentuk aktifitas nyata untuk mencapai tujuan tertentu.

Pengertian motivasi menurut para ahli:

Huitt, W. (2001) mengatakan motivasi adalah suatu kondisi atau status internal (kadang-kadang diartikan sebagai kebutuhan, keinginan, atau hasrat) yang mengarahkan perilaku seseorang untuk aktif bertindak dalam rangka mencapai suatu tujuan.

Thursan Hakim (2000:26) mengemukakan pengertian motivasi adalah suatu dorongan kehendak yang menyebabkan seseorang melakukan suatu perbuatan untuk mencapai tujuan tertentu.

Pengertian motivasi yang lebih lengkap menurut Sudarwan Danim motivasi diartikan sebagai kekuatan, dorongan, kebutuhan, semangat, tekanan, atau mekanisme psikologis yang mendorong seseorang atau sekelompok orang untuk mencapai prestasi tertentu sesuai dengan apa yang dikehendakinya.

Siswa pada dasarnya termotivasi untuk melakukan suatu aktivitas untuk dirinya sendiri karena ingin mendapatkan kesenangan dari pelajaran, atau merasa kebutuhannya terpenuhi.Ada juga Siswa yang termotivasi melaksanakan belajar dalam rangka memperoleh penghargaan atau menghindari hukuman dari luar dirinya sendiri, seperti: nilai, tanda penghargaan, atau pujian guru (Lepper: 1988). 
Dari beberapa pendapat para ahli di atas, dapat disimpulkan bahwa motivasi merupakan kondisi psikologis yang mendorong seseorang untuk melakukan sesuatu. Ada tiga komponen utama dalam motivasi yaitu kebutuhan, dorongan dan tujuan. Kebutuhan terjadi apabila individu merasa ada ketidakseimbangan antara apa yang ia miliki dan ia harapkan. Sedangkan dorongan merupakan kekuatan mental untuk melakukan kegiatan dalam rangka memenuhi harapan. Dorongan merupakan kekuatan mental yang berorientasi pada pemenuhan harapan atau pencapaian tujuan dan tujuan merupakan hal ingin di capai oleh seorang individu. Tujuan tersebut akan mengarahkan perilaku dalam hal ini yaitu perilaku untuk belajar.

\section{Motivasi Belajar}

Bertolak dari arti kata motivasi di atas, maka yang dimaksud dengan motivasi belajar adalah sesuatu yang menimbulkan dorongan atau semangat belajar atau dengan kata lain sebagai pendorong semangat belajar (Islamuddin, 2012:259). Sedangkat menurut Hermine Marshall, istilah motivasi belajar adalah kebermaknaan, nilai, dan keuntungan-keuntungan kegiatan belajar belajar tersebut cukup menarik bagi siswa untuk melakukan kegiatan belajar.

Motivasi belajar penting bagi siswa dan guru. Bagi siswa pentingnya motivasi belajar adalah sebagai berikut :

a. Menyadarkan kedudukan pada awal belajar, proses dan hasil akhir.

b. Contohnya: setelah siswa membaca suatu bab buku bacaan, di bandingkan dengan temannya sekelas yang juga bab tersebut, ia kurang berhasil menangkap isi, maka ia terdorong membaca lagi.

c. Menginformasikan tentang kekuatan usaha belajar yang dibandingkan dengan teman sebaya. Sebagai ilustrasi jika terbukti usaha belajar seorang siswa belum memadai maka ia berusaha maka ia berusaha setekun temannya yang belajar dan berhasil.

d. Mengarahkan kegiatan belajar, sebagai ilustrasi setelah ia ketahui bahwa bahwa dirinya belum belajar secara serius, seperti bersenda gurau di dalam kelas maka ia akan merubah perilaku belajarnya.

e. Membesarkan semangat belajar. Contohnya, seorang anak yang telah menghabiskan banyak dana untuk sekolahnya dan masih ada adik yang di biayai orang tua maka ia akan berusaha agar cepat lulus.

f. Menyadarkan tentang adanya perjalanan belajar dan kemudian bekerja, siswa dilatih untuk menggunakan kekuatannya sehingga dapat berhasil.Sebagai ilustrasi, setiap 
hari siswa di harapkan untuk belajar di rumah, membantu orang tua dan bermain dengan temannya. Apa yang di lakukan di harapkan dapat berhasil memuaskan.

Motivasi belajar juga penting diketahui oleh seorang guru. Pengetahuan dan pemahaman tentang motivasi belajar pada siswa bemanfaat bagi guru, manfaat itu sebagai berikut:

a. Membangkitkan, meningkatkan, dan memelihara semangat siswa.

Dalam hal ini pujian, hadiah, dorongan atau pemicu semangat dapat di gunakan untuk mengobarkan semangat belajar.

b. Mengetahui dan memahami motivasi belajar siswa di kelas yang bermacam-macam sehinnga dengan bermacamnya motivasi tersebut di harapkan guru dapat menggunakan bermacam-macam strategi belajar mangajar.

c. Meningkatkan dan menyadarkan guru untuk memilih satu diantara bermacammacam peran seperti sebagai penasihat, fasilitator, instruktur, teman diskusi, dan penyemangat.

\section{Jenis Motivasi}

Berdasarkan sifatnya, motivasi dapat dibedakan menjadi motif intrinsic dan motivasi ekstrinsik:

a. Motivasi Intrinsik

Motivasi intrinsik adalah motivasi yang timbul dari diri sendiri dan tidak dipengaruhi oleh sesuatu di luar dirinya karena dalam setiap diri individu sudah ada dorongan untuk melakukan sesuatu. Orang yang tingkah lakunya digerakkan oleh motivasi intrinsik, baru akan puas kalau tingkah lakunya telah mencapai hasil tingkah laku itu sendiri. Misalnya, orang yang gemar membaca tanpa ada yang mendorong, ia akan mencari sendiri buku-buku untuk dibacanya. Orang yang rajin dan bertanggung jawab tanpa menunggu komando, sudah belajar dengan sebaik-baiknya.

b. Motivasi Ekstrinsik

Jenis motivasi ini timbul sebagai akibat pengaruh dari luar individu, apakah karena adanya ajakan, suruhan, atau paksaan dari orang lain sehingga dengan keadaan demikian siswa mau melakukan belajar. Misalnya, siswa yang sedang menyelesaikan pekerjaan rumah, sekedar mematuhi perintah guru, kalau tidak dipatuhi guru akan memarahinya. 


\section{Prinsip-Prinsip Motivasi Belajar}

Motivasi mempunyai peranan yang strategis dalam aktivitas belajar seseorang.Tidak ada seorang pun yang belajar tanpa motivasi.Tidak ada motivasi berarti tidak ada kegiatan belajar.Agar peranan motivasi lebih optimal, maka prinsip-prinsip motivasi dalam belajar tidak hanya sekedar diketahui, tetapi harus diterangkan dalam aktivitas belajar-mengajar. Ada beberapa prinsip motivasi dalam belajar seperti dalam uraian berikut:

a. Motivasi sebagai Dasar Penggerak yang Mendorong Aktivitas Belajar

Seseorang melakukan aktivitas belajar karena ada yang mendorongnya.Motivasilah sebagai dasar penggeraknya yang mendorong seseorang untuk belajar.Minat merupakan kecenderungan psikologis yang menyenangi suatu objek, belum sampai melakukan kegiatan.Namun minat adalah motivasi dalam belajar.Minat merupakan potensi psikologi yang dapat dimanfaatkan untuk menggali motivasi. Bila seseorang sudah termotivasi untuk belajar, maka dia akan melakukan aktivitas belajar dalam rentang waktu tertentu. Oleh karena itulah, motivasi diakui sebagai dasar penggerak yang mendorong aktivitas belajar seseorang.

b. Motivasi Intrinsik Lebih Utama daripada Motivasi Ekstrinsik dalam Belajar

Dari seluruh kebijakan pengajaran, guru lebih banyak memutuskan memberikan motivasi ekstrinsik kepada setiap anak didik. Anak didik yang malas belajar sangat berpotensi untuk diberikan motivasi ekstrinsik oleh guru supaya dia rajin belajar. Efek yang tidak diharapkan dari pemberian motivasi ekstrinsik adalah kecenderungan ketergantungan anak didik terhadap segala sesuatu di luar dirinya. Selain kurang percaya diri, anak didik juga bermental pengharapan dan mudah terpengaruh. Oleh karena itu motivasi intrinsik lebih utama dalam belajar.

c. Motivasi Berupa Pujian Lebih Baik daripada Hukuman

Meski hukuman tetap diberlakukan dalam memicu semangat belajar anak didik, tetapi masih lebih baik penghargaan berupa pujian. Setiap orang senang dihargai dan tidak suka dihukum dalam bentuk apa pun juga. Memuji orang lain berarti memberikan penghargaan atas prestasi kerja orang lain. Hal ini akan memberikan semangat kepada seseorang untuk lebih meningkatkan prestasi kerjanya. Tetapi pujian yang diucap itu tidak asal ucap, harus pada tempat dan kondisi yang tepat. Kesalahan pujian bisa bermakna mengejek.

d. Motivasi Berhubungan Erat dengan Kebutuhan Belajar 
Dalam kehidupan anak didik, membutuhkan penghargaan, perhatian, ketenaran, status, martabat, dan sebagainya merupakan kebutuhan yang wajar bagi anak didik. Semuanya dapat memberikan motivasi bagi anak didik dalam belajar. Guru yang berpengalaman harus dapat memanfaatkan kebutuhan anak didik, sehingga dapat memancing semangat belajar anak didik agar menjadi anak yang gemar belajar. Anak didik pun giat belajar untuk memenuhi kebutuhannya demi memuaskan rasa ingin tahunya terhadap sesuatu.

e. Motivasi dapat Memupuk Optimisme dalam Belajar

Siswa yang mempunyai motivasi dalam belajar selalu yakin dapat menyelesaikan setiap pekerjaan.Dia yakin bahwa belajar bukan kegiatan yang sia-sia. Hasilnya akan berguna tidak hanya kini, tetapi juga di hari mendatang (Rahmah, 2002: 239).

\section{Bentuk -Bentuk Motivasi}

Ada beberapa bentuk dan cara untuk menumbuhkan motivasi dalam kegiatan belajar, di antaranya:

a. Memberi angka

Angka dalam hal ini sebagai simbol dari nilai kegiatan belajarnya.banyak siswa belajar,yang utama justru untuk mencapai angka atau nilai yang baik.sehingga siswa biasanya yang dikejar adalah nilai ulangan atau nila-nilai pada rapor angkanya yang baik-baik. Angka-angka yang baik itu bagi para siswa merupakan motivasi yang sangat kuat. Tetapi ada juga, bahkan banyak siswa bekerja atau belajar hanya ingin mengejar asalkan naik kelas saja. Namun demikian semua itu harus di ingat oleh guru bahwa pencapaian angka-angka seperti itu belum merupakan hasil belajar yang sejati, hasil belajar yang bermakna. Oleh karena itu, langkah selanjutnya yang ditempuh oleh guru adalah bagamana cara memberikan angka-angka dapat dikaitkan dengan values yang terkandung didalam setiap pengetahuan yang di ajarkan kepada para siswa sehinggga tidak sekedar kognitif saja, tetapi juga keterampilan dan afektinya.

b. Hadiah

Hadiah dapat juga di katakana sebagai motivas,tetapi tidaklah selalu demikian.karena hadia untuk suatu pekerjaan,mungkin tidak akan menarik bagi seseorang yang tidak senang dan tidak berbakat untuk sesuatu pekerjaan tersebut.sebagai contoh hadiah yang diberikan untuk gambar yang terbaik mungkin tidak akan menarik bagi seseorang siswa yang tidak memiliki bakat menggambar. 
c. Saingan/kompetisi

Saingan atau kompetisi dapat digunakan sebagai alat motivasi untuk mendorong belajar siswa.persaingan,baik persaingan individual maupun persaingan kelompok dapat meningkatkan prestasi belajar siswa.memamng unsur persaingan ini banyak dimanfaatkan di dalam dunia industri atau perdagangan,tetapi juga sangat baik di gunakan untuk meningkatan kegiatan belajar siswa.

d. Ego-involvement

Menumbuhkan kesadaran pada siswa agar merasakan pentingnya tugas dan menerimanya sebagai tantangan sehingga bekerja keras dengan mempertaruhkan harga diri,adalah sebagai salah satu bentuk motivasi yang cukup penting seseorang akan berusaha dengan segenap tenaga untuk mencapai prestasi yang baik dengan menjaga harga dirinya.penyelesaian tugas dengan baik adalah simbol kebanggaan dan harga diri,begitu juga untuk siswa si subyek belajar.para siswa akan belajar dengan keras bisa jadi karena harga dirinya.

e. Memberi ulangan

Para siswa akan menjadi giat belajar kalau mengetahui aka nada ulangan. Oleh karena itu, member ulangan ini juga merupakan sarana motivasi.Tetapi yang harus diingat oleh guru, adalah jangan selalu sering karena bisa membosankan dan bersifat rutinitas. Dalam hal ini guru juga harus terbuka, maksudnya kalau akan ulangan harus diberitahukan kepada siswanya

f. Mengetahui hasil

Dengan mengetahui hasil pekerjaan, apalagi kalau terjadi kemajuan, akan mendorong siswa untuk giat belajar. Semakin mengetahui bahwa grafik hasil belajar meningkat,maka akan ada motivasi pada diri siswa untuk terus belajar, dengan suatu harapan hasilnya terus meningkat.

g. Ujian

Apabila ada siswa yang sukses yang berhasil menyelesaikan tugas dengan baik, perlu diberikan pujian,pujian ini adalah bentuk reinforcement yang positif dan sekalgus merupakan motivasi yang baik

h. Hukuman

Sebagai reinforcement yang negative tetapi kalau diberikan secara tepat dan bijak bisa menjadi alat motivasi.Oleh karena itu guru juga harus memahami prinsip-prinsip pemberin hukuman. 
i. Hasrat untuk belajar

Hasrat untuk belajar, berarti ada unsure kesengajaan ada maksud ntuk belajar. Hal ini akan lebih baik, bila dibandingkan segala sesuatu kegiatan yang tanpa maksud.

j. Minat

Motivasi sangat erat hubungannya dengan minat.Motivasi muncul karena ada kebutuan.Juga minat sehingga tepatlah kalau minat merupakan alat motivasi yang pokok. Proses belajar itu akan berjalan lancar kalau disertai dengan minat.

\section{Macam-macam Motivasi}

a. Motivasi dilihat dari dasar pembentukannya

1) Motif-motif bawaan, yaitu motif yang di bawa sejak lahir, jadi motivasi itu ada tanpa dipelajari. Contoh: dorongan untuk makan, minum, bekerja, dan lain-lain.

2) Motif-motif yang dipelajari, maksudnya motif-motif yang timbul karena dipelajari. Sebagai contoh: dorongan untuk belajar suatu cabang ilmu pengetahuan, dorongan untuk mengajar sesuatu di dalam masyarakat. Motifmotif ini sering kali disebut dengan motif-motif yang diisyaratkan secara sosial. Di samping itu, Frandsen menambahkan jenis-jenis motif berikut ini;
a) Cognitive motives
b) Self-expression
c) Self-enhancement

b. Jenis motivasi menurut pembagian dari Woodworth dan Marquis

1) Motif atau kebutuhan organis, meliputi misalnya: kebutuhan untuk makan,minum, seksual, berbuat, dan kebutuhan untuk beristirahat

2) Motif-motif darurat. Yang termasuk dalam jenis motiv ini antara lai: dorongan untuk menyelamatkan diri, dorongan untuk membalas, untuk berusaha, untuk memburu, jelasnya motiv ini timbul karena rangsangan dari luar

3) Motif-motif objektif .dalam hal ini menyangkut kebutuhan untuk melakukan manipulasi, untuk menaruh minat. Motiv-motiv ini muncul karena dorongan untuk dapat menghadapi dunia luar secara efektif.

c. Motivasi jasmaniah dan rohaniah

Ada beberapa ahli yang menggolongkan jenis motivasi itu menjadi dua jenis yakni motivasi jasmania dan motivasi rohaniah. Yang termasuk motivasi jasmani seperti misalnya reflex, insting otomatis, nafsu.Sedangkan yang termasuk motivasi rohaniah adalah kemuan. 
Soal kemauan itu pada setiap diri manusia terbentuk dari empat momen yaitu:

1) Momen timbulnya alasan, sebagai contoh seorang pemuda yang sedang giat berlatih olah raga utnuk menghadapi suatu porseni di sekolahnya tetapi tiba-tiba di suruh ibunya untuk mengantarkan seorang tamu membeli tiket karena tamu itu mau kembali ke Jakarta.

2) Momen pilih

Momen pilih maksudnya dalam keadaan pada waktu ada alternatif-alternatif yang mengakibatkan persaingan diantara alterntif atau alasan-alasan itu. Kemudian sesorang menimbang berbagai alrternatif untuk kemudian menentukan pilihan yang akan di kerjakan.

3) Momen putusan

Dalam persaingan antara berbagai alasan, sudah barang tentu akan berakhir dengan dipilihnya satu alternatif yang dipilih inilah yang menjadi putusan untuk dikerjakan.

4) Momen terbentuknya kemauan kalau seseorang sudah menetapkan satu putusan untuk dikerjakan, timbullah dorongan pada diri seseorang utnuk bertindak, melaksanakan putusan itu.

\section{Peranan Motivasi dalam Proses Pembelajaran}

Proses pembelajaran merupakan kegiatan yang melibatkan seseorang individu (jasmani dan rohani), kegiatan pembelajaran tidak pernah dilakukan tanpa adanya dorongan atau motivasi yang kuat dari dalam diri individu ataupun dari luar individu yang mengikuti kegiatan pembelajaran. Adapun peranan motivasi dalam pembelajaran adalah sebagai berikut (Wasty, 2006: 12-15).

1. Peran motivasi sebagai motor penggerak atau pendorong kegiatan pembelajaran. Motivasi dalam hal in berperan sebagai motor penggerak terutama sebagai siswa untuk belajar, baik berasal dari dalam dirinya (internal) maupun dari luar diri (eksternal) untuk melakukan proses pembelajaran.

2. Peran motivasi memperjelaskan tujuan pembelajaran. Motivasi bertalian dengan suatu tujuan, tanpa ada tujuan, maka tidak akan ada ada motivasi seseorang. Oleh sebab itu motivasi sangat berperan penting dalam mencapai hasil pembelajaran siswa menjadi optimal. Dengan demikian motivasi dapat memberikan arah dan kegiatan bagi siswa (peserta didik) yang harus dikerjakan sesuai dengan tujuan tersebut. 
3. Peran motivasi menyeleksi arah pembuatan.disini motivasi dapat berperan menyeleksi arah pembuatan bagi siswa apa yang harus dikerjakan guna mencapai tujuan.

4. Peran motivasi internal dan eksternal dalam pembelajaran. Dalam kegiatan pembelajaran, motivasi internal biasanya muncul dari dalam diri siswa, sedangkan motivasi eksternal siswa dalam pembelajaran umum didapat dari guru (pendidik).

5. Peran motivasi melahirkan prestasi. Motivasi sangat berperan dalam pembelajaran siswa dalam meraih prestasi belajar. Tinggi rendahnya prestasi belajar seorang siswa (peserta didik) selalu dihubungkan dengan tinggi rendahnya motivasi pembelajaran seorang siswa tersebut.

\section{E. Peranan Guru dalam Meningkatkan Motivasi Belajar Siswa}

Peran guru dalam meningkatkan motivasi belajar siswa adalah salah satu kegiatan integral yang wajib ada dalam kegiatan pembelajaran. Selain memberikan dan mentransfer ilmu pengetahuan guru juga bertugas untuk meningkatkan motivasi anak dalam belajar. Tidak bisa dipungkiri bahwa semangat belajar seorang siswa dengan yang lain berbedabeda, untuk itulah penting bagi guru untuk selalu senantiasa untuk membertikan motivasi kepada siswa supaya siswa senantiasa memiliki semangat belajar dan mampu menjadi siswa yang berprestasi serta dapat mengembangkan diri secara optimal.

Proses pembelajaran akan berhasil apabila siswa mempunyai motivasi dalam belajar. Oleh karena itu guru perlu menumbuhkan motivasi belajar siswa yang optimal. Guru dituntut kreatif untuk membangkitkan motivasi belajar siswa.

Adapun peran guru dalam meningktkan motivasi belajar siswa sebagai beriku:

1. Menjadikan siswa yang aktif dalam kegiatan belajar mengajar

Guru memberikan arahan kepada siswa dengan memberikan ilmu pengetahuan dan memberikan pertanyaan-pertanyaan dan siswapun mengerjakan tugas dengan baik dengan tujuan untuk menumbuhkan motivasi siswa dalam belajar sehingga siswa dapat menyelesaikannya dengan tuntas, contohnya: setelah guru memberikan ilmu kepada siswa lalu guru memberikan pertanyaan dan siswa menjawab pertanyaan dengan tuntas.

2. Menciptakan suasana kelas yang kondusif

Kelas yang kondusif disini adalah kelas yang aman, nyaman dan selalu mendukung siswa untuk bisa belajar dengan suasana yang tenang dan mendukung proses pembelajaran dengan tata ruang sesuai yang diharapkan. 
3. Menciptakan metode pembelajaran yang bervariasi

Metode pembelajaran bervariasi ini agar siswa tidak bosan dan jenuh dalam suatu pembelajaran maka diciptakanlah pembelajaran yang bervariasi. Tujuannya agar siswa selalu termotivasi dalam kegiatan proses pembelajaran.

4. Meningkatkan antusias dan semangat dalam mengajar

Kepedulian seorang guru dalam proses belajar mengajar merupakan faktor yang sangat penting untuk menumbuhkan motivasi belajar siswa. Karena apabila guru tidak antusias dan semangat dalam proses belajar mengajar maka siswa tidak akan termotivasi dalam belajar.

5. Memberikan penghargaan

Pemberian penghargaan ini bisa berupa nilai, hadiah, pujian, dan sebagainya agar siswa termotivasi akan belajar dan selalu ingin menjadi yang terbaik.

6. Menciptakan aktivitas yang melibatkan siswa dalam kelas

Ciptakan aktivitas yang melibatkan siswa dengan teman-teman mereka dalam satu kelas. Tujuannya agar satu sama lain akan membagikan pengetahuan, gagasan, atau ide dalam penyelesaian tugas invidu siswa dengan seluruh siswa di kelas.

Dari uraian di atas bahwa peran guru dalam motivasi belajar ini sangatlah penting, apabila guru tida ikut serta dalam motivasi belajar siswa maka siswa kurang kreatif dan tidak terpancing untuk bersikap aktif. Maka dari itu peran guru sangatlah berpengaruh terhadap motivasi belajar siswa dan tujuan utamanya untuk mencapai prestasi dan meningkatkan mutu belajar dalam proses pembelajaran.

\section{PENUTUP}

\section{Kesimpulan}

1. Guru menurut UU no. 14 tahun 2005 "adalah pendidik profesional dengan tugas utama mendidik, mengajar, membimbing, mengarahkan, melatih, menilai, dan mengevaluasi peserta didik pada pendidikan anak usia dini jalur pendidikan formal, pendidikan dasar, dan pendidikan menengah."

2. Peran seorang guru sangatlah signifikan dalam proses belajar mengajar. Peran guru dalam proses belajar mengajar meliputi banyak hal seperti sebagai pengajar, manajer kelas, supervisor, motivator, konsuler, eksplorator.

3. Motivasi berasal dari bahasa Latin, Movere yang berarti dorongan atau daya penggerak. Banyak ahli yang sudah mengemukakan pengertian motivasi dengan berbagai sudut 
pandang mereka masing-masing, namun intinya sama, sebagai suatu pendorong yang mengubah energi dalam diri seseorang kedalam bentuk aktifitas nyata untuk mencapai tujuan tertentu.

\section{DAFTAR PUSTAKA}

Hamalik, Oemar. 2011. Kurikulum dan Pembelajaran.Jakarta : Bumi Aksara.

Islamuddin, Haryu. 2012. Psikologi Pendidikan. Cet.I. Pustaka Pelajar.

Marno dan Idris. 2010. Strategi \& Metode Pengajaran.Cet. VII. Yogyakarta:Ar-ruzz Media.

Roemah, Noer. 2012. Psikologi Pendidikan. Cet.I. Yogyakarta: Teras.

Soemanto, Wasty. 2006. Psikologi Pendidikan. Cet.V. Jakarta: Asdi Mahasatya.

Syah, Muhibbin.2004. Psioklogi Belajar. Jakarta: Raja Grafindo Persada.

Uzer, Usman. 2007. Menjadi Guru Profesionjal. Cet.I-XXII. Bandung Remaja Rosdakarya. 